\title{
Explaining loan rate differentials between small and large companies: evidence from Switzerland
}

\author{
Andreas Dietrich
}

Accepted: 1 February 2010/Published online: 20 March 2010

(C) Springer Science+Business Media, LLC. 2010

\begin{abstract}
The lending-rate differentials between loans to small and large companies are striking. According to several studies, these disparities of loan rates are primarily a result of a lower informational efficiency at small companies. This study examines to what extent such differences in loan rates are caused not only by informational inefficiencies, but also by operational costs and the borrower's negotiation power. By using unique, hand-collected data from the credit-pricing models of 15 Swiss regional banks, we provide new empirical evidence that operational costs are a key factor in explaining differences in lending rates between small and large enterprises. Furthermore, we also found that the lack of negotiation power of small enterprises-expressed in the profit margin amount of the bank-has significant explanatory power.
\end{abstract}

Keywords Small business finance $\cdot$ Loan pricing · Operational costs · Determination of interest rates · Relationship lending

JEL Classifications D23 - E43 - G14 ·

G21 - L26

A. Dietrich $(\bowtie)$

Institute of Financial Services IFZ, Lucerne University of Applied Sciences and Arts, Grafenauweg 10, 6304

Zug, Switzerland

e-mail: andreas.dietrich@hslu.ch

\section{Introduction}

It is a widely held view that, despite recent trends of financial disintermediation and growth in marketbased finance, bank lending is essential to the performance and operation of modern economies. Above all, small and medium-sized enterprises (SMEs), which typically cannot access public debt markets, heavily depend on bank-intermediated capital.

According to the Swiss Federal Statistical Office (2008), SMEs in Switzerland, i.e., enterprises with a staff headcount less than 250, account for $99.7 \%$ of all firms and $67 \%$ of total employment, and have a substantial impact on economic growth. Hence, lending to small businesses has been a crucial subject in the economic discourse and has become a significant area of research in finance. During the past 15 years, small business lending has attracted a considerable amount of academic attention. A large number of these studies have examined the effects of differences in borrower characteristics on the availability and the terms of credit to small firms (see, e.g., Petersen and Rajan 1994, 1995; Berger and Udell 1995, 1998; Cole 1998; Berger et al. 1998; Cole et al. 2004).

This empirical research has largely been based on data collected in response to policy concerns about the availability and the terms of credit for small firms in the 1990s. The severity of the current global financial crisis is unprecedented in modern times. Therefore, it is understandable that discussions have 
again arisen regarding the fundamental issues related to availability and terms of credit for small and medium-sized enterprises.

The issues of credit availability and credit costs matter most for small and mid-sized enterprises for two reasons. First, and as stated above, SMEs are more bank-dependent than large enterprises because SMEs typically do not have access to the public debt and/or equity markets. Second, SMEs are more vulnerable to information problems because small business borrowers tend to be more informationally opaque than larger businesses.

This paper focuses on loan rates, investigating its determinants in relation to borrower size. In particular, we examine to what extent differences in loan rates are a function of (1) operational costs (including the application, screening and monitoring costs as well as the ongoing running costs of lending) and (2) negotiation power. In order to analyze the differentials in loan volumes, we decompose the loan rate into its various components. Based on empirical evidence (see, e.g., Prognos 1998), we assume that the loan volume is highly and positively correlated with the size of the borrowing enterprise.

At present, it is not clear which factors determine the differentials between loans to small and to large companies. According to several studies, the striking disparities of loan rates to small and large companies result from the lower informational efficiency of small companies. We hypothesize that, besides the information asymmetries, operational costs of the bank and the borrowers' negotiation power are also relevant explanatory factors influencing the lending differentials between loans to small and large companies.

In order to address the research question of this paper, we must analyze credit-pricing models of various banks. As banks do not publish this (internal and confidential) information, we were able to gain access to and hand-collect data concerning the different components of a credit price as a function of loan volume, credit risk rating and credit maturity. We gathered the following data from 15 Swiss banks. In order to make the credit pricing models comparable, we focus on data for commercial loans with a fixed interest rate.

Our analysis of the lending rates for SMEs differentiates in several important ways from previous studies. First, unlike the existing literature on SME finance, our examination does not focus on the aspect of relationship lending and the information asymmetry aspect. By using a unique hand-collected dataset, we determine to what extent differences in lending rates are a result of bank's operational costs and by the borrowers' negotiation power. As mentioned above, the existing literature has largely neglected operational costs, as well as the aspect of the borrowers' negotiation power as an explanatory factor for the differentials between loan rates to small and large companies.

Second, our data set from the Swiss market is unique, as the relevant pricing structure information is not publicly available. Our data contain extensive information about the credit pricing of Swiss regional banks. To our best knowledge, no previous study has analyzed this kind of information. Hence, this study is the first to look into the "black box" of bank loanpricing models.

Third, data from Switzerland offer an advantageous environment in which these issues can be analyzed. The sophisticated loan-pricing models of Swiss banks are very similar to loan-pricing models of banks in other competitive Western European countries and the US. Fourth, a large fraction of the Swiss economic activity is driven by SMEs, just as is the case in the US and Europe.

The remainder of this paper is structured as follows: In Section 2, we survey the relevant academic literature and show how our study contributes to the analysis of this important public policy question related to the loan rate differentials between small and large companies. Section 3 contains a presentation of the basic model on which our survey and hypotheses are based. Section 4 describes the data and methodology used to test our hypotheses. In Section 5, we present the results from our empirical analyses. In Section 6, we provide a summary and conclusions.

\section{Theoretical background}

The broadly acknowledged work of Stiglitz and Weiss (1981) suggests that mainly asymmetric information problems can explain the existence of a loan market disequilibrium characterized by excess demand for credit. Later, attention began to shift to the examination of how banks alleviate the problems that arise from asymmetric information about borrower quality. 
Empirical studies have found that problems created by asymmetric information are more acute for SMEs than for large enterprises because the former are informationally more opaque (e.g., Berger and Udell 1998). Researchers thus began to examine how banks and other financial institutions might mitigate information problems in commercial lending to SMEs. Research mainly focused on the credit availability and specific contract terms-such as interest rates and collaterals-that banks use in constructing commercial loan contracts. Empirical findings in the field of credit availability point out that the strength of the bankborrower relationship is positively related to credit availability (Petersen and Rajan 1994, 1995; Berger and Udell 1995; Cole 1998; Elsas and Krahnen 1998; Harhoff and Körting 1998; Scott and Dunkelberg 1999; Degryse and Van Cayseele 2000; Cole et al. 2004). Moreover, the strength of the bank-borrower relationship is also positively related to various credit terms. Borrowers with longer banking relationships pay lower interest rates (e.g., Berger and Udell 1995; Blackwell and Winters 1997; Harhoff and Körting 1998; Scott and Dunkelberg 1999; Degryse and Van Cayseele 2000; Bodenhorn 2003; Peltoniemi 2007), have greater protection against the interest rate cycle (e.g., Berlin and Mester 1998; Ferri and Messori 2000) and are also empirically associated with reduced collateral requirements (e.g., Berger and Udell 1995; Harhoff and Körting 1998; Cole 1998; Elsas and Krahnen 1998; Machauer and Weber 1998; Scott and Dunkelberg 1999).

The literature on the relationships between credit terms (interest rates) and company size is very limited. Hartwell (1947) provided very early empirical evidence that loan size and interest rates are negatively correlated. Using credit information on 21,669 loans of the Federal Reserve's Functional Cost Analysis Program, Murphy (1983) found that economies of scale exist in the commercial loan market and that small loans to small firms are thus relatively more costly for the lenders. By using a sample of individual loans from a major bank in the UK, Cressy and Toivanen (2001) found that collateral provisions and loan size reduce the interest rate paid and that better borrowers get larger loans and lower interest rates. Similar to this study, Hanley and Girma (2006) used UK bank data for 466 new venture loan applications during the period 1998 until 1999. They confirmed the results from Cressy and Toivanen
(2001) that firms with larger credits enjoy discounted interest margins and that the amount borrowed is positively related to the collaterals. The authors explain these relationships by the diversification model (Barro 1976; Coco 2000) and the costly state verification model (Bester 1994). According to these models, larger loans should, other things equal, carry a higher risk of being squandered by the borrower. Accordingly, lenders need to cut margins for higher loans in order to ease the overall repayment burden and to reduce moral hazard.

Academic literature on credit availability and lending terms to SMEs in Switzerland is almost inexistent. A study by Prognos (1998) analyzed the relationships between small and medium-sized enterprises and the Swiss banks. The authors point out that $87 \%$ of the 4,838 SMEs examined have bank loans, and that $54 \%$ of these enterprises maintain a single banking relationship. Analyzing the referring loans, they found that $90 \%$ of the respective interest rates were in a range of 350 basis points and that there was a negative relationship between enterprise size and lending rates. A further study by Fasano and Gfeller (2003) analyzed 2,350 small and medium-sized companies in Switzerland; it concluded that SMEs have a good relationship with their banks overall. However, many SMEs perceived the rating and price setting process by the banks as not transparent enough.

Overall, the literature on credit terms (interest rates) in relation to loan and company size has been focusing mostly on relationship lending. As mentioned above and according to this strand of literature, differences in credit terms are mainly explained by information asymmetry aspects and can be reduced by a strong relationship between the bank and its borrowers. Other possibly relevant determinants of loan rate differentials have been remarkably absent in literature.

As pointed out above, we assume that the loan amount requested by an enterprise is highly correlated to its size. The relationship between company size and loan volume might not always be exactly proportional because especially small companies tend to have a relatively higher percentage of credits in their balance sheet total compared to larger companies. However, a study from Prognos (1998), analyzing the Swiss credit market, provides strong empirical evidence for a positive relation between loan volumes and enterprise size. The authors divide enterprise 
size, measured by the sales volume, into six different categories and report the average loan volume for each group. The respective correlation coefficients for these groups are 0.99 for investment loans (number of observations: 3,345 companies) and 0.94 for mortgage loans (number of observations: 1,393 companies).

The Survey of Small Business Finances (SSBF) provides more detailed data for the US SME market. It collects information on small businesses, such as owner characteristics, firm size, use of financial services and loan volumes, of companies with fewer than 500 employees in the US. The data show that the correlation coefficient between company size, measured by the sales volume, and the loan volume was-depending on the credit type-between 0.50 and 0.67 in 1998 and 0.40 and 0.65 , respectively, in 2003. Based on the strong empirical evidence provided by these studies, we subsequently assume that large enterprises also have higher loan volumes. ${ }^{1}$

\section{Model and hypotheses}

In this section, we present a model that explains the various components of banks' lending rates as a function of credit volume and company size, respectively. This model serves as the basis of our research and data survey, as it shows that differences in loan rates between small and large enterprises are not only caused by information asymmetries, but also by differing operational costs and negotiation power issues. The purpose of the model is to determine the factors influencing the differences in lending rates between small and large loans and enterprises, respectively. To understand the model, it is important to know that the different cost factors of the lending rates are summed up, as shown in Fig. 1.

The model can be described as follows:

(1) The size of loan demanded by an enterprise is proportional to its size (for further explanations: see above).

(2) The funding costs of a bank are not determined by the borrower size. Therefore, these costs

\footnotetext{
${ }^{1}$ Furthermore, please note that our data structure forces us to make this assumption, given that we have information on the loan size only.
}

are-independent of the borrower sizeidentical. $^{2}$

(3) Furthermore-if also almost negligiblescreening costs of the refused credit applications have to be added. Enterprises that were granted a loan have to pay for the screening costs of the enterprises whose credit applications were refused. The more credit applications that are refused on a percentage basis, the higher is the percentage surcharge on the interest rate. We assume that these costs are evenly distributed among the enterprises, regardless of enterprise size.

(4) We assume the bank's profit margin for loans to be smaller for larger loan volumes and enterprises because larger enterprises possess more negotiation power than small enterprises. Larger enterprises also have-in contrast to small ones-the possibility to raise capital at the bond or stock market.

(5) The banks' operational costs of lending (application/screening, monitoring and running costs of lending), expressed as a percentage of the loan amount, are higher for small credits than for larger ones because certain costs are fixed. This means that-in absolute numbers-operational costs for small loans are smaller than for larger loans, but relatively seen, small credits are more expensive than larger ones. The marginal operational costs thus decrease with the loan volume. Given that smaller enterprises are also granted lower credit volumes, smaller enterprises have to pay for higher (relative) operational costs.

(6) In theory, the risk-related costs (likewise expressed as a percentage of the loan amount) are not dependent on enterprise size. However, we assume that the risk-related costs are relatively higher for small borrowers than for larger ones, not because their business activities inherently involve higher risk, but rather because banks are not able to accurately assess the risk in lending to such enterprises, and because larger and often older firms have a better track record. Small enterprises usually have higher information asymmetries (a lower

\footnotetext{
${ }^{2}$ However, differences exist in the funding costs between banks as these costs are determined by various macroeconomic factors, the bank-specific rating and the size of the bank.
} 


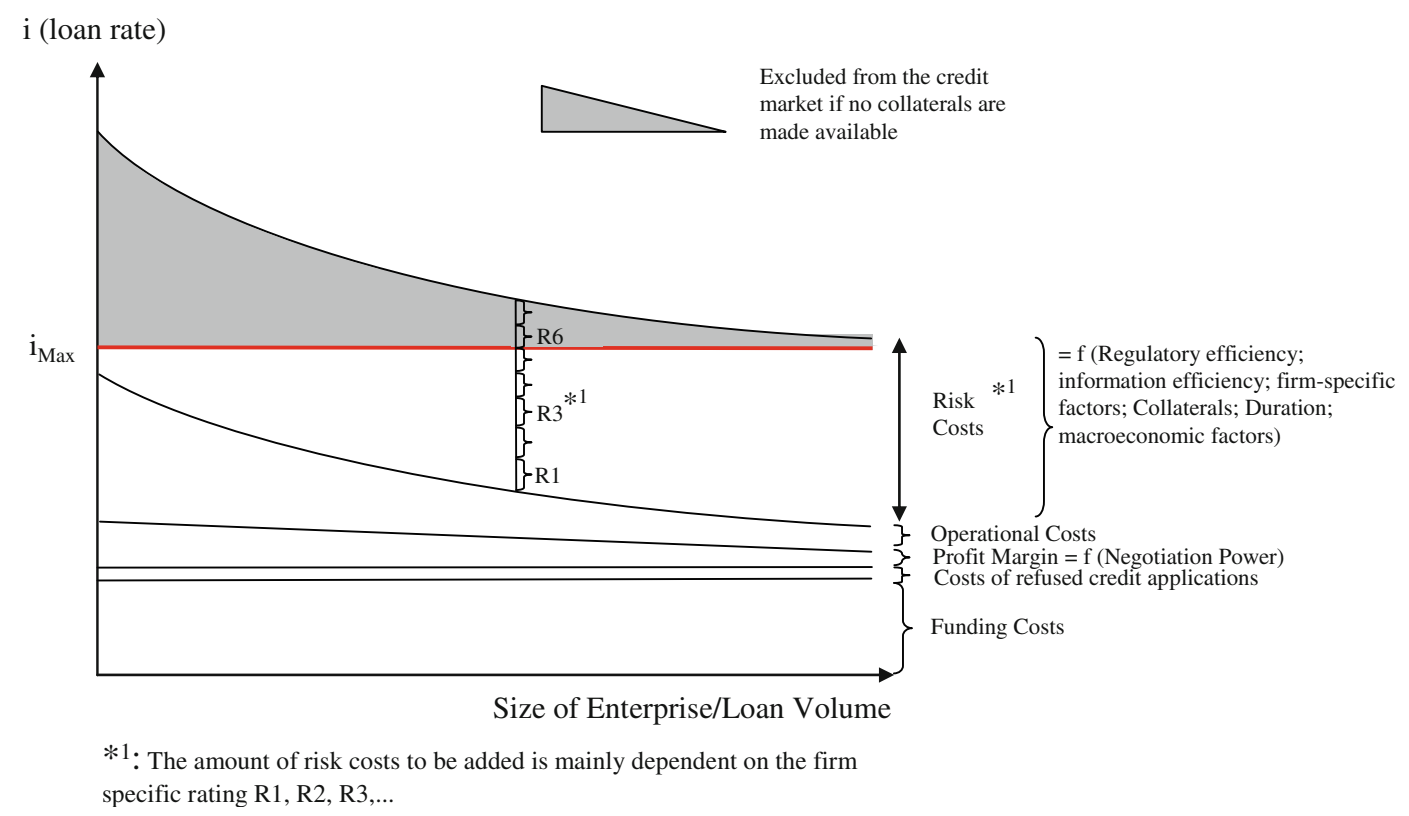

Fig. 1 Interest rate as a function of loan volume and enterprise size. This figure depicts the relationship between loan volume (size of enterprise, respectively) and loan rate. The model illustrates the influence of various bank lending rates

information efficiency, respectively) as they often do not have a sophisticated accounting and controlling system, because young companies do not have track records yet, because there is no contemporary (market) rating for smaller enterprises, or because SMEs often develop niche products in new markets, which are difficult to assess for the banks. ${ }^{3}$

(7) In the past decades, legal maximum interest rates have been eliminated in nearly all countries. Nonetheless, experience has shown that banks usually do not raise their interest rates beyond a certain limit (see Stiglitz and Weiss 1981). Usually, banks do not increase the interest rate they charge above a certain rate, even in the face of an excess demand for funds and even if there are enterprises, which offer to pay more than this respective interest rate, called $i_{\max }$ (see Fig. 1). Banks do not lend loans

\footnotetext{
3 Other factors influencing the risk-related costs are the duration of the credit, the collaterals or the exogenously determined regulatory capital adequacy costs (Basle I and II). Furthermore, also macroeconomic factors such as the GDP growth are relevant determinants of the risk assessment.
}

components on lending rate differentials between small and large enterprises. The different cost factors of the lending rates are summed up. Own illustration

anymore because if they did, the expected rate of return might decrease beyond this point. Therefore, enterprises will only be eligible to borrow if they generate costs of less than $i_{\max }$. However, the interest rate is not the only important term of the contract. The amount of collateral the bank demands of loan applicants will also affect both the behavior of borrowers and the credit allocation. Collateral requirements make borrowers less willing to take risks, which increases the return to the bank. Therefore, enterprises may have the opportunity to get loans at lower risk costs by providing collaterals.

Derived from the model above and based on the assumption that loan volume is highly and positively correlated with firm size of the borrower, the following hypotheses are formulated:

Hypothesis 1 There is a negative correlation between loan size and the interest rate, i.e., the average credit costs for small loans and small enterprises are higher than for large loans and large enterprises, under the assumption of an identical rating. 
Hypothesis 2 The smaller the loan is, the higher its (relative) operational costs are. Therefore, the operational costs of a bank are a key explanatory factor in explaining differences in lending rates between small and large loans and companies, respectively.

We assume that the amount of operational costs positively correlates with the lending amount, but that the marginal operational costs decrease by loan volume. This might be the case as a certain amount of fixed operational costs incurs independently of the loan volume. The banks' operational costs expressed as a percentage of the loan amount are, therefore, higher for small credits (and small enterprises) than for larger ones. Small credits are thus-relatively seen-more expensive.

Hypothesis 3 We expect that, given the same rating, the bank's profit margin for loans to larger enterprises is smaller because larger enterprises possess more negotiation power than do small enterprises. As we assume that loan volume and firm size are highly correlated, we expect the profit margin to be higher for large loans than for small loans.

\section{Data and methodology}

The data source for our investigation is a survey conducted by the author during 2006. The sample for this unique, hand-collected dataset consists of information from 15 Swiss commercial banks that reported data on their pricing models for commercial loans. The empirical part of this study is thus based upon data on the credit-pricing models of these banks. In order to render the information comparable, banks were asked to report data for commercial loans with fixed interest rates. In order to analyze the differences by loan volume, banks provided data for interest rates on loans in four buckets: up to CHF 100,000, CHF 300,000 , CHF 1,000,000 and CHF 5,000,000. The interest rates for these loan volumes were recorded in relation to different credit durations (1 year, 3 years and 5 years) and rating categories. Furthermore, the data reflect the prices for new loan agreements. Note that the investigated banks provided data on credit pricing models, not on individual loans, so that we do not have data for individual loans.

Given that banks use various rating models with different classifications, we focus on interest rates for prime borrowers. This allows us to render the information across the various banks comparable. Moreover, we asked the surveyed banks to decompose their interest rates into their various components.

Note that the banks provided this information on a strictly confidential basis. Therefore, we are allowed to report average values of the pricing models, but are not authorized to report loan-pricing calculations by individual banks. The participating banks were providing data mainly in order to be able to compare their loan costs and credit-price models with the (average) price models of their competitors.

The banks participating in this study are classified-according to the official statistics maintained by the Swiss National Bank-as "cantonal banks," "regional and savings banks" and "other banks." All banks are primarily active in the lending business and operate in the northern, eastern and central part of Switzerland. The total assets of the banks of our sample vary between CHF 1 billion and CHF 30 billion.

Switzerland has a small and very competitive banking market. As we are analyzing different bank types and various commercial bank sizes, the results obtained from this sample can be generalized also to a larger population of interest. The behavior of banks mainly active in other parts of Switzerland-and even banks active in other Western economies-is expected to be similar to the results we are gathering here. Swiss banks are most likely to allocate loans with very similar pricing models to the ones used by US or European banks.

To empirically investigate the effect of loan volume on total loan rate, operational costs and profit margin, we use a linear regression model. We use

\footnotetext{
${ }^{4}$ Cantonal banks are either $100 \%$ State-owned or partially State-owned banks. They vary both in size and in their business activities. Cantonal banks are engaged in all banking businesses with an emphasis on lending/deposit business and operate primarily in the market of their home canton. All the Cantonal Banks account for around $30 \%$ of commercial banking business in Switzerland. Regional and savings banks are mainly small banks focusing on traditional banking and limited to often very small geographical areas. The group "other banks" includes banks with various business objectives. For our sample, only banks active in the traditional lending business (mainly Group 5.11—commercial banks, according to the official statistics maintained by the Swiss National Bank) are considered for the analyses.
} 
OLS regressions with robust standard errors to estimate the coefficients in our model. We also control for serial correlation within firms by clustering at the bank level.

We use total loan rate, operational costs and profit margin as our dependent variables. Loan volume, bank size, bank type and loan term are the independent variables in our estimations. Loan volume refers to commercial loans with fixed interest rates in the CHF 100,000, CHF 300,000, CHF 1,000,000 and CHF 5,000,000 buckets. Bank size is measured by the accounting value of the bank's total assets as published in the annual report of 2006. Bank type refers to the banking categories as defined by the Swiss National Bank (SNB). We test whether there are statistically significant differences in the dependent variables among the three banking categories in our sample "cantonal banks," "regional and savings banks" and "other banks." Loan term refers to the amount of time that a borrower is given to pay off a commercial loan with fixed interest rates. For our sample, we gathered data for loans of 1 year, 3 years and 5 years. As mentioned above, data on total loan rate, operational costs, profit margin and loan term are provided by 15 Swiss commercial banks and reflect costs for new loan agreements for a commercial loan with fixed interest rates.

\section{Results}

Figure 2 illustrates the pricing structure of commercial loan volumes of CHF 300,000 with a fixed interest rate, averaged over the 15 commercial banks in our sample. We first divide the loan rates into three factors: (1) funding costs, (2) interest rate spread without the risk premium (including operational costs, regulatory costs and profit margin) and (3) risk premium. The risk premium as shown in Fig. 2 is the maximal amount a borrower has to pay. Dependent on the individual rating, the risk premium varies on average between $0.16 \%$ (prime borrower) and $3.03 \%$ (for a riskier borrower that is still granted a credit) for a loan with a maturity of 1 year. Borrowers who do not meet the rating criteria are excluded from the credit market.

First, there is empirical evidence that the interest rate of commercial loans is increasing in duration although its credit spread (without the risk premium)

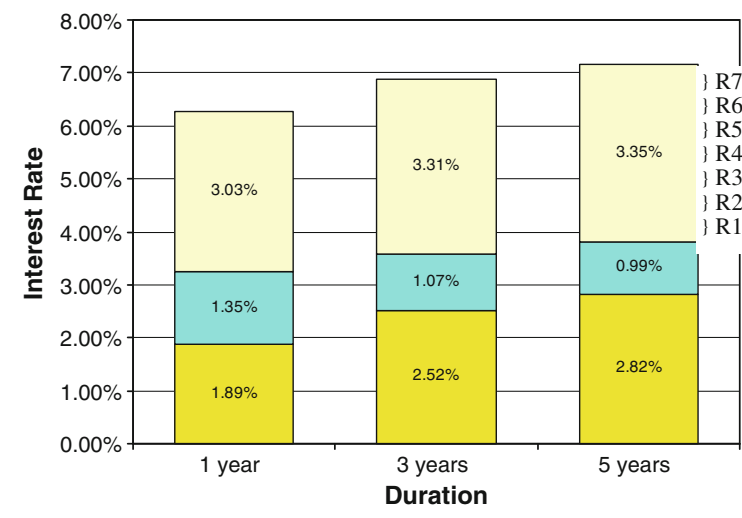

$\square$ Risk Premium $\square$ Spread without Risk Premium $\square$ Funding Costs

Fig. 2 Loan rate components, CHF 300,000. This figure reports the average interest rates for a commercial loan of CHF 300,000 with fixed durations of 1 year, 3 years and 5 years. The interest rates reflect the prices for new loan agreements. The amount of the risk premium to be added is dependent on the firm-specific rating R1, R2, R3, etc. The time period covers the year 2006. The pricing-specific information was provided by 15 Swiss commercial banks. Own calculations

is decreasing. The maximal interest rate charged by a bank in our sample in 2006 for a loan of CHF 300,000 averages $6.27 \%$ for a 1 -year loan, $6.90 \%$ for a 3-year loan and $7.16 \%$ for a loan over 5 years. The standard deviations are $0.63 \%$ for the 1 -year, $0.75 \%$ for the 3-year and $1.15 \%$ for the 5-year lending contract, respectively. Not surprisingly, the main reasons for the increasing interest rates in duration are the funding costs and a growing probability of default by the borrower. Note, however, that the credit spread (without the risk premium) is decreasing in duration of the credit contract by 36 basis points.

In order to examine the latter observation more closely, we further decompose the credit spread for a commercial loan into its various factors. As the banks of our sample use different rating models with various rating classifications, we will focus our analyses on loans to prime borrowers. This allows us to render the information of the pricing models of these banks comparable.

Table 1 illustrates the various cost factors for a loan volume of CHF 300,000 for a prime borrower. Again, all values below reflect the average costs per bank. In accordance with Fig. 2 above, loan rates in Table 1 can be divided into the three factors: (1) funding costs, (2) interest rate spread without the risk 
Table 1 Decomposition of the loan rate for prime borrowers, CHF 300,000

\begin{tabular}{|c|c|c|c|c|}
\hline Amount of credit: CHF 300,000 & 1 Year & 3 Years & 5 Years & \\
\hline Expected loss & $\begin{array}{l}0.16 \% \\
(0.12)\end{array}$ & $\begin{array}{l}0.22 \% \\
(0.16)\end{array}$ & $\begin{array}{l}0.28 \% \\
(0.18)\end{array}$ & Risk premium \\
\hline Profit margin & $\begin{array}{l}0.09 \% \\
(0.06)\end{array}$ & $\begin{array}{l}0.07 \% \\
(0.06)\end{array}$ & $\begin{array}{l}0.06 \% \\
(0.06)\end{array}$ & \\
\hline Regulatory costs & $\begin{array}{l}0.13 \% \\
(0.05)\end{array}$ & $\begin{array}{l}0.13 \% \\
(0.06)\end{array}$ & $\begin{array}{l}0.13 \% \\
(0.08)\end{array}$ & \\
\hline Operational costs, summary & $\begin{array}{l}0.83 \% \\
(0.31)\end{array}$ & $\begin{array}{l}0.57 \% \\
(0.21)\end{array}$ & $\begin{array}{l}0.50 \% \\
(0.20)\end{array}$ & Spread without risk premium \\
\hline Screening costs & $0.58 \%$ & $0.28 \%$ & $0.21 \%$ & \\
\hline Monitoring costs & $0.21 \%$ & $0.24 \%$ & $0.25 \%$ & \\
\hline Running costs & $0.05 \%$ & $0.05 \%$ & $0.05 \%$ & \\
\hline Indirect costs & $\begin{array}{l}0.30 \% \\
(0.12)\end{array}$ & $\begin{array}{l}0.30 \% \\
(0.12)\end{array}$ & $\begin{array}{l}0.30 \% \\
(0.12)\end{array}$ & \\
\hline Funding costs & $\begin{array}{l}1.89 \% \\
(0.03)\end{array}$ & $\begin{array}{l}2.52 \% \\
(0.06)\end{array}$ & $\begin{array}{l}2.82 \% \\
(0.08)\end{array}$ & Funding costs \\
\hline Average prime interest rate & $3.40 \%$ & $3.81 \%$ & $4.09 \%$ & \\
\hline
\end{tabular}

This table reports the average interest rates for a commercial loan of CHF 300,000 with fixed durations of 1 year, 3 years and 5 years for a prime borrower. The interest rates reflect the prices for new loan agreements. All numbers are in \%. Standard deviations are in brackets. These data cover the year 2006. The pricing specific information was provided by 15 Swiss commercial banks

premium (including operational costs, regulatory costs and profit margin) and (3) risk premium.

Operational and funding costs apparently represent a significant part of the interest rate of a credit for a prime borrower. Although the operational costs for a 1 -year loan are twice as high as the operational costs for a 3-year loan, the cost-covering interest rate for a 1-year loan is still lower due to different funding costs. As there is also a small probability of default for a borrower with a prime rating, there is at least a $0.16 \%$ risk premium for a 1 -year, $0.22 \%$ for a 3 -year and $0.28 \%$ for a 5 -year credit. Overall, companies rated as "excellent" have to pay on average a minimum credit rate of $3.40 \%$ for a 1 -year loan, $3.81 \%$ for a 3 -year loan and $4.09 \%$ for a 5 -year loan if the amount is CHF 300,000 (see Table 1).

In order to examine the differences between small and larger loans more in detail, we now analyze the pricing structure of commercial loans with a volume of CHF 1,000,000. Again, we report the average cost factors of the interest rates for a commercial loan with fixed durations of 1 year, 3 years and 5 years for a borrower with a prime rating. Loan rates in Table 2 are again decomposed into the three factors: (1) funding costs, (2) interest rate spread without the risk premium (including operational costs, regulatory costs and profit margin) and (3) risk premium.

Data on interest rates of commercial loans of CHF 1,000,000 confirm that the spread (without the individual risk premium) is lower, the longer the duration of the credit contract is. Comparing the results in Table 1 and Table 2, we see that the credit interest rate spread is lower for a higher loan amount.

An in-depth analysis of the operational costs and the profit margin for commercial loans results in the following findings: For a commercial loan volume of CHF 1,000,000, prime borrowers have an average loan rate of $2.83 \%$ if the loan duration is 1 year, $3.43 \%$ if it is 3 years and $3.76 \%$ if it is 5 years. Interest rates for a commercial credit volume of $\mathrm{CHF}$ 1,000,000 are-as described above-lower than for one of CHF 300,000. As illustrated in Table 2, the main reasons for these differentials are the operational costs. While the total amount of operational costs does not significantly vary across loan volumes, their relative (in percentage) amount decreases with the loan size. A certain amount of fixed operational costs incurs independently of the loan volume. Banks consider in their credit pricing models that screening 
Table 2 Decomposition of the loan rate for prime borrowers, CHF 1,000,000

\begin{tabular}{|c|c|c|c|c|}
\hline Amount of credit: CHF $1,000,000$ & 1 Year & 3 Years & 5 Years & \\
\hline Expected loss & $\begin{array}{l}0.16 \% \\
(0.12)\end{array}$ & $\begin{array}{l}0.22 \% \\
(0.16)\end{array}$ & $\left.\begin{array}{l}0.28 \% \\
(0.18)\end{array}\right\}$ & Risk premium \\
\hline Profit margin & $\begin{array}{l}0.07 \% \\
(0.07)\end{array}$ & $\begin{array}{l}0.08 \% \\
(0.07)\end{array}$ & $\begin{array}{l}0.07 \% \\
(0.07)\end{array}$ & \\
\hline Regulatory costs & $\begin{array}{l}0.13 \% \\
(0.05)\end{array}$ & $\begin{array}{l}0.13 \% \\
(0.06)\end{array}$ & $\begin{array}{l}0.13 \% \\
(0.08)\end{array}$ & \\
\hline Operational costs, summary & $\begin{array}{l}0.28 \% \\
(0.08)\end{array}$ & $\begin{array}{l}0.18 \% \\
(0.05)\end{array}$ & $\begin{array}{l}0.16 \% \\
(0.05)\end{array}$ & Spread without risk premium \\
\hline Screening costs & $0.16 \%$ & $0.11 \%$ & $0.10 \%$ & \\
\hline Monitoring costs & $0.20 \%$ & $0.19 \%$ & $0.19 \%$ & \\
\hline Running costs & $0.16 \%$ & $0.12 \%$ & $0.14 \%$ & \\
\hline Indirect costs & $\begin{array}{l}0.30 \% \\
(0.12)\end{array}$ & $\begin{array}{l}0.30 \% \\
(0.12)\end{array}$ & $\begin{array}{l}0.30 \% \\
(0.12)\end{array}$ & \\
\hline Funding costs & $\begin{array}{l}1.89 \% \\
(0.03)\end{array}$ & $\begin{array}{l}2.52 \% \\
(0.06)\end{array}$ & $\begin{array}{l}2.82 \% \\
(0.08)\end{array}$ & Funding costs \\
\hline Average prime interest rate & $2.83 \%$ & $3.43 \%$ & $3.76 \%$ & \\
\hline
\end{tabular}

This table reports the average interest rates for a commercial loan of CHF 1,000,000 with fixed durations of 1 year, 3 years and 5 years for a prime borrower. The interest rates reflect the prices for new loan agreements. All numbers are in \%. Standard deviations are in brackets. These data cover the year 2006. The pricing specific information was provided by 15 Swiss commercial banks

and monitoring costs for loans of CHF 300,000 or CHF 1,000,000 do not differ significantly.

In contrast, banks do not differentiate among enterprise sizes when calculating their indirect costs (marketing, accounting costs, etc.). They usually add a certain percentage-neither considering the loan volume nor its maturity. This procedure, even if imprecise, is reasonable, as an accurate allocation of indirect costs to various cost units is difficult.

The profit margin for both above-mentioned credit loan volumes is very low. The interviewed bank representatives stated that this amount is often less than 10 basis points.

Furthermore, the costs of refused credit applications are not separately calculated and included in the credit pricing models in our bank sample. These costs are included in the operational costs. Enterprises that were granted a loan do, therefore, not explicitly pay for the screening costs of the enterprises whose credit applications have been refused. Based on the data available, we cannot show if these costs are evenly distributed among the different enterprise sizes.

Figure 3 summarizes and completes the above presented results. It illustrates the average interest rates for commercial loans of $\mathrm{CHF} 100,000$, CHF 300,000 , CHF 1,000,000 and CHF 5,000,000 by decomposing the lending rates into six different components. The commercial loans presented below have fixed durations of 3 years and are calculated based on a loan for a prime borrower.

Figure 3 illustrates that the lending rate in Switzerland is negatively correlated with the loan volume and, according to our assumption, enterprise size. The lending rate for a small loan is, on average, higher than for large loan volumes, even though the rating is the same. The descriptive statistics also demonstrate that operational costs of a bank are dependent on loan size. Operational costs seem to be a key element in explaining loan rate differentials between small and large loans and companies, respectively. Based on the data as shown in Fig. 3, it is not clear whether the profit margin is also correlated with loan volume.

In the next step, we run several regressions to test whether the loan rate, the operational costs and the profit margin are determined by the loan volume, as hypothesized above. As control variables, we use bank size, bank type and loan term. Bank size is measured by the accounting value of the bank's total 


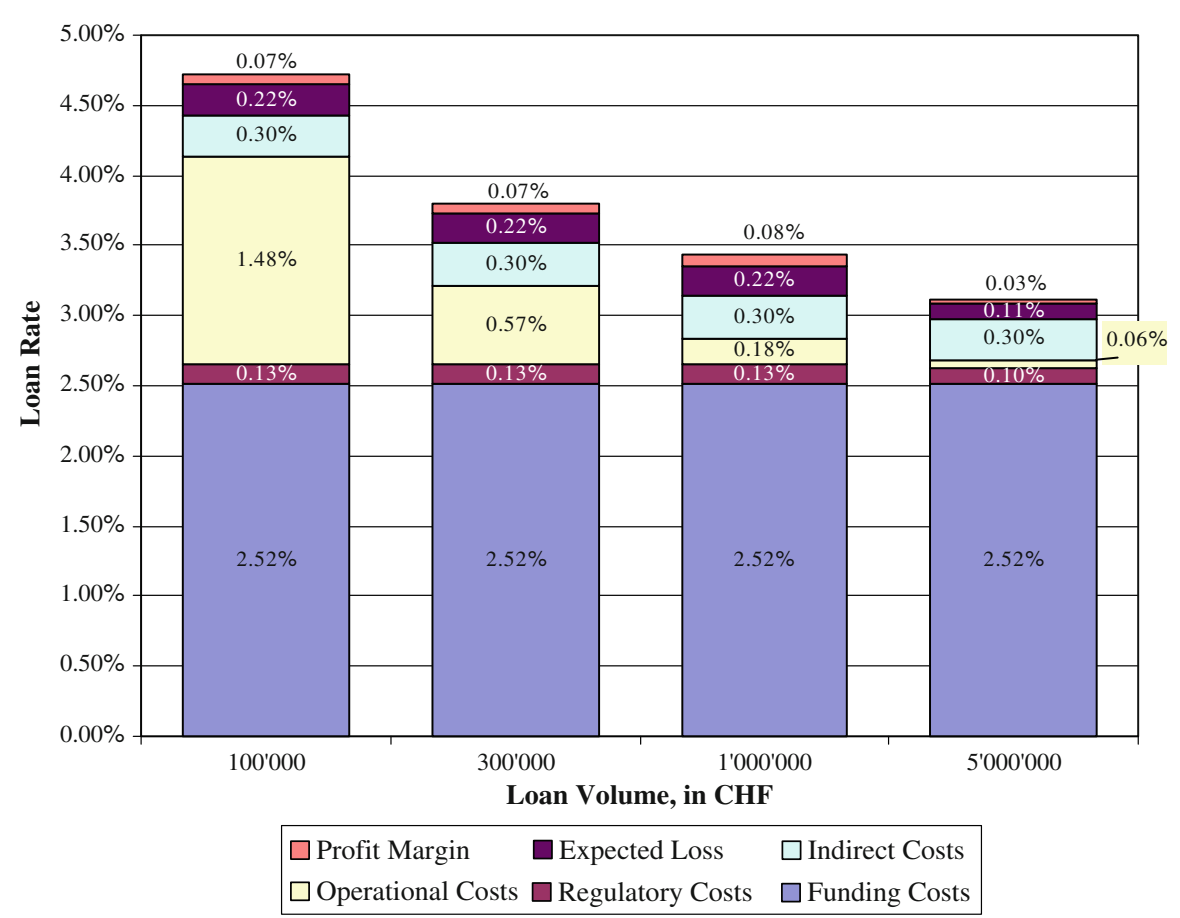

Fig. 3 Prime loan rate components by loan volumes. This figure reports the average interest rates for commercial loans of CHF 100,000, CHF 300,000, CHF 1,000,000 and $\mathrm{CHF}$ $5,000,000$ by decomposing the lending rate into six different components. The commercial loans have fixed durations of 3 years and are calculated based on a loan for a prime borrower. The interest rates reflect the prices for new loan agreements.

assets. Loan term refers to the amount of time that a borrower is given to pay off a loan. Bank type refers to the banking categories as defined by the Swiss National Bank (SNB). We test whether there are differences in the dependent variables among the banking categories "cantonal banks," "regional and savings banks" (Dummy_RB) and "other banks" (Dummy_Other).

Table 3 reports the regression results. The first column presents the results when the loan rate is our dependent variable. Column two shows the estimation with the operational costs as our dependent variable. Column three illustrates the results with the profit margin as dependent variable. The explanatory power of the model varies across the three estimations. The included variables explain best the total loan rate, for which the adjusted $R^{2}$ amounts to $50 \%$. Furthermore, we are able to explain $31 \%$ of the variation of the total operational costs, and about $18 \%$ of the variation of the profit margin. The variance inflation factors (VIFs) of the
All numbers are in \%. The time period covers the year 2006. The pricing specific information was provided by 15 Swiss commercial banks for CHF 100,000, CHF 300,000 and CHF 1,000,000. Data for loans over CHF 5,000,000 are based on credit pricing model information by 12 Swiss commercial banks (Color figure online)

independent variables indicate that there is no multicollinearity problem. ${ }^{5}$

The regression results show that a higher loan volume leads to significantly lower interest rates, with the coefficient being significant at the $1 \%$ level. Lending rates in Switzerland are negatively correlated with loan volume and, according to our assumption, enterprise size. We thus have evidence to confirm Hypothesis 1.

The coefficient of the variable loan term is significantly positive, which meets our expectation. The main reasons for increasing interest rates in duration are the funding costs (in times of a normal

\footnotetext{
$\overline{5 \text { In order to }}$ check for multicollinearity, we computed variance inflation factors (VIFs) for all independent variables based on our OLS regression. VIFs are obtained by regressing an explanatory variable $i$ on all other independent variables. As a rule of thumb, VIFs greater than 10 would indicate a problem of multicollinearity (see Gujarati 1995). In case of our reference model, VIFs range from 1 to 1.64 ; thus, multicollinearity does not seem to be a problem.
} 
Table 3 Regression results

\begin{tabular}{lccc}
\hline & $\begin{array}{l}\text { (1) Loan } \\
\text { rate }\end{array}$ & $\begin{array}{l}\text { (2) Operational } \\
\text { costs }\end{array}$ & $\begin{array}{l}\text { (3) Profit } \\
\text { margin }\end{array}$ \\
\hline Loan volume & $-0.274 * * *$ & $-0.209^{* * *}$ & $-0.010^{* * * *}$ \\
& $(0.015)$ & $(0.017)$ & $(0.003)$ \\
Loan term & $14.341^{* * *}$ & $-9.547^{* * *}$ & $-0.466^{* * *}$ \\
Bank size & $(1.556)$ & $(1.184)$ & $(0.142)$ \\
& 0.000 & 0.000 & -0.000 \\
Dummy_RB & $(0.000)$ & $(0.001)$ & $(0.000)$ \\
Dummy_Other & -3.216 & -21.461 & 2.524 \\
& $(7.229)$ & $(23.301)$ & $(3.433)$ \\
Constant & $36.565 * * *$ & 2.640 & -1.804 \\
& $(7.333)$ & $(16.838)$ & $(2.503)$ \\
Observations & 174 & $123.552^{* * *}$ & $9.727 * * *$ \\
Adj. $R^{2}$ & 0.50 & 0.31 & $(1.505)$ \\
\hline
\end{tabular}

The table reports results from OLS estimations of the effects of loan volume, loan term, bank size and bank category on (1) lending rates (in basis points), (2) operational costs (in basis points) and (3) profit margin (in basis points). The dummy variables bank category refer to the official classification of banks by the Swiss National Bank (SNB). The dummy variables take the value of one if the bank belongs to the respective category, and zero otherwise. The banking groups in our sample are the cantonal banks (reference category), the regional and savings banks (Dummy_RB), and the other banks (Dummy_Other). The full sample includes 174 observations from 15 banks. The period covers the year 2006. Bank size is expressed in 1,000 CHF, loan volume in 10,000 CHF. Robust standard errors appear in parentheses. $* * *, * *$, and $*$ indicate statistical significance at the $1 \%, 5 \%$ and $10 \%$ levels, respectively

yield curve) and a growing probability of default by the borrower. The results of Ortiz-Molina and Penas (2008), investigating the determinants of the maturity of lines of credit to small businesses, provide strong support for the hypothesis that shorter loan maturities serve to mitigate the problems associated with asymmetric information that are typical for small business lending. They find that maturity is shorter for smaller firms that are more informationally opaque. We found evidence that smaller firms might also prefer shorter loan maturities because of the negative correlation of loan term and loan rates. Loan term (maturity) is not only a substitute mechanism in mitigating agency problems, but also negatively affects the loan rate.

Furthermore, we found evidence that banks from the bank category "other banks" have significantly lower credit rates that "cantonal banks." On the other hand, bank size does not influence the credit pricing loan rates.

Our regression results with the operational costs as dependent variable confirm Hypothesis 2. The loan volume has a negative and significant effect on operational costs, with the coefficient being significant at the $1 \%$ level. The marginal operational costs are decreasing in loan volume: The smaller the loan volume is, the higher are the (relative) operational costs.

As mentioned above, this relationship has been mostly neglected in existing literature, but is of major importance. As the average difference between the operational costs for new loan agreements of CHF 100,000 and of CHF 5,000,000 amounts to 142 basis points, operational costs of a bank should be considered as a key factor in explaining differences in lending rates between small and large loan volumes and-according to our empirically supported assumption of loan size and company size being positively correlated-companies. Relationship lending can help to lower these differentials in operational costs, as screening costs for an established customer relationship are lower than for a new customer. Relationship lending might help to reduce the differentials in operational lending costs for a loan of CHF 100,000 and a loan of CHF 5,000,000 by maximal 70 basis points. However, operational costs for small loans are still higher than for large loans as marginal running costs and marginal monitoring costs also decrease with loan volume and cannot be significantly reduced through relationship lending.

The coefficient of the loan term variable is statistically highly significant and negative. The operational costs are decreasing in duration of the credit contract, mainly through the fact that the screening costs are spread across more years. Furthermore, we found that bank category and bank size do not affect operational costs. Banks in our sample do not seem to have significant differences in operational costs.

Finally, the regression results show that profit margins are significantly lower for larger loans, and thus are lower for larger companies than for small companies, with the coefficient being significant at the $1 \%$ level. Negotiation power-as approximated by the bank's profit margin-significantly explains differentials between interest rates for small and large loans. We can thus also confirm Hypothesis 3. 
The coefficient of the loan term variable has a highly significant negative relationship with the profit margin. Furthermore, we can see from the estimation results that bank size and bank category do not have a statistically significant effect on profit margin.

However, we have to be careful when analyzing results of the profit margin. First, profit margin is an imperfect proxy for measuring negotiation power. Second, the descriptive statistics reveal that differences in profit margins are rather small overall. Third, the investigated banks only provided us with information on their average profit margins; profit margins differ from loan to loan even within a bank and a defined loan amount, as it is within the competence of loan officers to add a certain percentage value.

As Machauer and Weber (1998) point out, negotiation power might also be a function of the rating group to which the borrower belongs, as well as of the company's size. Furthermore, in negotiating terms of lending, a bank often makes concessions because it is involved in other profitable businesses with the customer. In this case, the entire earnings of the customer must be taken into account. Gorton and Kahn (1996) also show that it is rational for the bank to lower loan rates for special classes of bad borrowers during the credit period in order to give them an incentive not to add risk inefficiently. Therefore, negotiation power of a company, when measured by the amount of the profit margin of banks, does not seem to be (solely) a function of size.

As several authors have pointed out, SMEs are more vulnerable to asymmetric information problems since small companies tend to be more informationally opaque than larger businesses (see, e.g., Berger and Udell 1998). The referring information asymmetries are primarily reflected in the risk premium that banks charge for the credit. Unfortunately, our data derived from the banks' credit-pricing models do not allow us to isolate and quantify the influence of information asymmetries on lending rate differentials between small and large companies.

Furthermore, as a robustness test, we also used the natural logarithm of bank assets and built dummy variables for two groups "small banks" and "large banks" as alternative size variables in our analyses. The results from these alternative specifications are not qualitatively different from what is presented in the table.

\section{Summary and conclusions}

In this study, we analyze lending rate differentials between small and large loan volumes by using data based on credit-pricing models from 15 Swiss commercial banks. We find that the average lending rate differentials between small loans and large loans are striking. Based on the empirically tested assumption that company size and loan volume are highly correlated, we thus provide empirical evidence that there is a negative relation between firm size and bank lending rates.

Several studies on relationship lending have shown that disparities of loan rates are primarily a result of lower informational efficiencies of small companies. By decomposing the interest rate into its various components, this study shows that operational costs (screening, monitoring and running costs of lending) are an additional relevant factor in explaining the differentials in lending rates between small and large sized loans and thus—-based on our assumption —also in lending rates between small and large firms. The banks' marginal operational costs are decreasing with loan size. Operational costs can explain up to 140 basis points of the differences in the lending rates for new loan agreements in the Swiss credit market. Relationship lending might help to lower these differentials in operational costs, as screening costs can be reduced through a long-term relationship. However, operational costs for small loans are still higher than for large loans, as marginal running and monitoring costs also decrease by loan volume and cannot be significantly reduced through relationship lending.

The lack of negotiation power of small enterprises-expressed in terms of a higher profit margin of the bank-does also explain differentials between loan rates for small loan amounts (and small companies, respectively) and loan rates for larger volumes (and loan rates to large companies, respectively). However, the borrowers' negotiation power might not only be a function of firm size but of the rating group the borrower belongs to and cross-selling aspects.

Overall, our empirical results provide evidence that operational costs and negotiation power are important determinants of lending rate differentials between loans to small companies and loans to large companies. Our study thus contributes to the existing literature by adding and quantifying these additional explanatory factors. 
A limitation of our study is that our data rely on credit pricing models from 15 Swiss commercial banks and that we do not have individual loan data. However, only the use of data derived from credit pricing models allows to decompose interest rate spreads into its different factors. Moreover, there is anecdotal evidence that theoretical prices usually equal the individual loan rates.

Furthermore, constructing a variable reflecting negotiation power in basis points is a very difficult task. Our study might rely on an imperfect proxy by using the bank's profit margin as negotiating power variable. Negotiation power might also be a function of the rating group the borrower belongs to and cross-selling aspects. However, calculating negotiation power based on theoretical pricing models is difficult.

The hypotheses we investigate are not specific to certain countries. However, our empirical study is focusing on the Swiss credit market. The role of operational costs as a determinant of differentials in lending rates for small and large loan amounts might be even more important in countries with a lower operational efficiency of the banking sector than Switzerland. Therefore, we believe that further exploring the determinants of loan rates differentials between small and large enterprises is a promising area for future research.

Acknowledgments The author would like to thank the representatives of various banks for data provision, and Gabrielle Wanzenried, Rebel Cole, the reviewers of this manuscripts and the participants of the 20th Annual Entrepreneurial Finance Conference (Las Vegas, 2008) for their insightful comments.

\section{References}

Barro, R. (1976). The loan market, collateral, and rates of interest. Journal of Money, Credit, and Banking, 8(4), 439-456.

Berger, A. N., Saunders, A., Scalise, J. M., \& Udell, G. F. (1998). The effects of bank mergers and acquisitions on small business lending. Journal of Financial Economics, 50(2), 187-229.

Berger, A. N., \& Udell, G. F. (1995). Relationship lending and lines of credit in small firm finance. Journal of Business, 68(3), 351-381.

Berger, A. N., \& Udell, G. F. (1998). The economics of small business finance: The roles of private equity and debt markets in the financial growth cycle. Journal of Banking \& Finance, 22(6-8), 613-637.
Berlin, M., \& Mester, L. J. (1998). On the profitability and cost of relationship lending. Journal of Banking \& Finance, 22(6-8), 873-897.

Bester, H. (1994). The role of collateral in a model of debt renegotiation. Journal of Money, Credit, and Banking, 26(1), 72-86.

Blackwell, D., \& Winters, D. (1997). Banking relationships and the effect of monitoring on loan pricing. Journal of Financial Research, 20(2), 275-289.

Bodenhorn, H. (2003). Short-term loans and long-term relationships: relationship lending in Early America. Journal of Money, Credit and Banking, 35(4), 485-505.

Coco, G. (2000). On the use of collateral. Journal of Economic Surveys, 14(2), 191-214.

Cole, R. A. (1998). The importance of relationships to the availability of credit. Journal of Banking \& Finance, 22(6-8), 959-977.

Cole, R., Goldberg, L., \& White, L. (2004). Cookie-cutter versus character: The micro structure of small-business lending by large and small banks. Journal of Financial and Quantitative Analysis, 39(2), 227-251.

Cressy, R., \& Toivanen, O. (2001). Is there adverse selection in the credit market? Venture Capital, 3(3), 215-238.

Degryse, H., \& Van Cayseele, P. J. (2000). Relationship lending within a bank-based system: evidence from European small business data. Journal of Financial Intermediation, 9(1), 90-109.

Elsas, R., \& Krahnen, J.-P. (1998). Is relationship lending special? Evidence from credit-file data in Germany. Journal of Banking \& Finance, 22(10-11), 1283-1316.

Fasano, M., \& Gfeller, T. (2003). Herausforderungen im Dia$\log$ zwischen KMU und Banken: Eine repräsentative Befragung des Staatssekretariats für Wirtschaft (SECO) in Zusammenarbeit mit Schweizer Wirtschaftsdachverbänden, Zurich.

Ferri, G., \& Messori, M. (2000). Bank-firm relationships and allocative efficiency in northeastern and central Italy and in the south. Journal of Banking \& Finance, 24(6), 10671095.

Gorton, G. B., \& Kahn, J. A. (1996). The design of bank loan contracts, collateral, and renegotiation. Working Paper No. 4273. National Bureau of Economic Research.

Gujarati, D. N. (1995). Basic econometrics. New York: McGraw Hill.

Hanley, A., \& Girma, S. (2006). New ventures and their credit terms. Small Business Economics, 26(4), 351-364.

Harhoff, D., \& Körting, T. (1998). Lending relationships in Germany-Empirical evidence from survey data. Journal of Banking \& Finance, 22(10-11), 1317-1353.

Hartwell, J. M. (1947). Interest rates by loan size and geographical region. Journal of the American Statistical Association, 42(238), 242-245.

Machauer, A., \& Weber, M. (1998). Bank behavior based on internal credit ratings of borrowers. Journal of Banking \& Finance, 22(10-11), 1355-1383.

Murphy, N. B. (1983). Loan rates, operating costs and size of loan: The evidence from cross-section data. In P. Horvitz \& R. Pettit (Eds.), Small business (pp. 51-62). Connecticut: JAI Press.

Ortiz-Molina, H., \& Penas, M. (2008). Lending to small businesses: The role of loan maturity in addressing 
information problems. Small Business Economics, 30(4), 361-383.

Peltoniemi, J. (2007). The benefits of relationship banking: Evidence from small business financing in Finland. Journal of Financial Services Research, 31(2), 153-171.

Petersen, M., \& Rajan, R. G. (1994). The benefits of lending relationships: Evidence from small business data. Journal of Finance, 49(1), 3-37.

Petersen, M., \& Rajan, R. G. (1995). The effect of credit market competition on lending relationships. Quarterly Review of Economics, 110(2), 407-443.

Prognos. (1998). Die Zusammenarbeit der kleinen und mittleren Unternehmen mit den Banken-Ergebnisse der KMUBefragung vom Sommer '98.
Scott, J. A. \& Dunkelberg, W. C. (1999). Bank consolidation and small business lending: A small firm perspective. In R. Lang (Ed.), Business access to capital and credit (pp. 328-361). Federal Reserve Bank of Dallas.

Stiglitz, J. E., \& Weiss, A. (1981). Credit rationing in markets with imperfect information. American Economic Review, 71(3), 393-410.

Swiss Federal Statistical Office. (2008). Betriebszählung, Unternehmensstruktur, Neuchâtel. 